\title{
REPRESENTASI GANGGUAN PSIKOLOGIS TOKOH ORANG PERTAMA DAN ORANG KEDUA DALAM NASKAH DRAMA "ALJABAR" KARYA ZAK SORGA : TELAAH PSIKOLOGI SASTRA
}

\author{
Ika NurDayana ${ }^{1)}$, Hidayah Budi Qur'ani' ${ }^{2)}$ \\ ${ }^{1), 2)}$ Pendidikan Bahasa dan Sastra Indonesia Fakultas Keguruan dan Ilmu Pendidikan, \\ Universitas Muhammadiyah Malang, Indonesia, Jalan Raya Tlogomas No. 246 \\ Malang, Jawa Timur, Indonesia, 65144, \\ IIkandfhm123@gmail.com \\ 2qurani@umm.ac.id
}

Diterima:

Direvisi:

Disetujui: DD MM YYYY

\begin{abstract}
ABSTRAK
Penelitian ini bertujuan mendeskripsikan bentuk gangguan psikologis yang dialami tokoh pelukis orang pertma dan orang kedua, serta drama menganalisis konteks awala gangguan psikologis yang diderita oleh tokoh orang pertama dan orang kedua dalam naskah drama "ALJABAR". Adapun relevansi yang terdapat pada naskah drama "ALJABAR" yang ada pada kehidupan sehari-hari pada kehidupan nyata pada masa ini. Masalah pada penelitian adalah adanya gangguan psikologis yang mempengaruhi kepribadian tokoh orang pertama dan tokoh orang kedua dalam naskah drama "ALJABAR" yang dilatarbelakangi oleh pengalaman dimasalalunya yang berpanguruh pada keberlangsungan kehidupanya. Untuk mengupas hal tersebut digunakan teori psikoanalisis dan dinamika kepribadian Sigmund Freud. Teori psikoanalisis digunakan sebagai pembedah ganguan psikologis yang terjadi.Dinamika kepribadian digunakan untuk membedah struktur kepribadian tokoh orang pertaa dan orang kdua. Penelitian ini merupakan penelitian kualitatif. Sumber data yang digunakan pada penelitian ini adalah nasakah "ALJABAR" karya Zak Sorga, sedangkan data yang digunakan dialog antar tokoh yang terdapat pada naskah drama "ALJABAR". Hasil dari penelitian ini adadalah bentuk ganguan psikologis dan faktor yang melatrbelakanginya anatara lain: (1) Emosi , (2) Agresi , (3) Seks , (4) Kecemasan , (5) Faktor Masalalu.
\end{abstract}

Kata Kunci: Dinamika Kepribadian, Gangguan Psikologis, Sigmund Freud

\section{PENDAHULUAN}

Psikologi adalah salah satu itu ilmu yang memiliki fokus aspek kejiwaan manusia. Psikologi sastra merupakan bentuk interdisipliner, adanya kedua ilmu yang membaur mebentuk sastu kesatuan, yaitu psikologi dan sastra. Kedua ilmu tersebut berlainan akan tetapi, tidak terlelpas dari kemunkinan untuk saling mlengkapi. Sastra yang tidak bisa jauh dri psikologi yang memiliki keterkaitan dalam sebuah karya sastra yang sangat kaya akan aspek kejiwaan didalamnya.

Sastra memiliki satu kencendrungan berbicara tentang rasa, rasa yang dimaksud dalam sastra adalah rasa yang lekat denga pribadi. Pada dasarnya yang menjadi objek dari psikologi sastra adalah aspek kemanusiaan yang ada pada diri tokoh fiksional yang terdapat dalam sebuah karya sastra yang diciptakan. Gangguan 
Ika NurDayana1), Hidayah Budi Qur'ani' ${ }^{2)}$ : Refresentasi Gangguan Psikologis Tokoh Orang Pertama dan Orang Kedua dalam Naskah Drama " Aljabar" Karya Zak Sorga: Te;aah Psikologi Sastra.

Website : https://jurnal.umj.ac.id/index.php/penaliterasi Email : penaliterasi@umj.ac.id

psikologis merupakan adanya seseorang yang memiliki cara berfikir dan perilaku, serta emosi yanng abnormal. Gangguan psikologis yang terjadi pada suatu individu didasari oleh faktor-faktor salah satunya adalah ingatan masalalu yang membayangbayangi dapat mempengaruhi kepribadian, dimana tekanan-tekanan yang ditimbulkan dari ingatan tersebut akan meberikan dorongan untuk menghancurkan dirinya dan bisa berujung pada kematian (Freud, 2015:36). Representasi gangguan psikologis pada umumnya tidak hanya ada didunia nyata, dalam karya sastra yang dilahirkan oleh seorang sastrawan dengan menonjolkan tokoh yang memiliki karakter berbeda-beda.

Gangguan psikologis yang ada pada tokoh merupakan bentuk imajinatif pengarang dalam memainkan lakon yang ada dalam suatu karya sastra, sama halnya dengan naskah drama "ALJABAR" yang menisahkan adanya gangguan psikologis yang terjadi pada tokoh orang pertama dan tokoh orang kedua, yang dilatarbelakangi oleh pengalaman masalalunya yang mengakibatkan ia harus mengalami gangguan psikologis pada dirinya. Adanya gangguan psikologis orang pertama dan orang kedua tersebut mengakibatkan ia mencoba melakukan sesuatu yang beerifat membahayakan dirinya bahkan dengan percobaan untuk mengakhiri hidupnya.

Pemilihan bahan penelitian ini didasri dengan adanya permsalahan gangguan psikologis yang terjadi pada tokoh orang pertama dan kedua dalam naskah drama "ALJABAR" karya Zak Sorga. Sama halnya gangguan psikologis yang terjadi pada tokoh orang pertama,yang bermula dari adanya bayangan di masalalu yang mempengaruhi keadaan psikologis dari tokoh orang kedua,dengan adanya gangguan psikologis yang terjadi pada tokoh orang kedua sangat mempengaruhi keberlangsungan hidupannya.Pada naskah drama "ALJABAR" banyak ditemukan penyelewengan moral pada masa mudanya yang dilakukan oleh tokoh orang kedua,dengan adanya penyelewengan tersebut mengakibatkan ingatan pada masalalunya yang kurang baik dan sangat memberikan dampak pada kepribadian tokoh orang kedua.

Sejauh penelusuaran pustaka peneliti menemukan 1 penenitian yang mengkaji naskah drama "ALJABAR". Peneltian dilakukan oleh, Syamsul Arifin (2017) yang berjudul Analisis Teknik Pelatihan Aktor Via Negativa Jerzy Grotowski Pada Naskah "ALJABAR" Karya Zak Sorga, penelitian ini menggunakan teori Growski vianegativa dan metode yang digunakan deskriptif, penelitian tersebut digunakan untuk memenuhi tugas akhir.Adapun penelitian yang menggunakan teori psikoanalisis Sigmund Freud yang digunakan pada naskah drama Kajian Psikoanalisis Tokoh-Tokoh Dalam Music Karya Jean-Luc Lagarce, penelitian ini mengugunakan teori Sigmund Freud psikoanalisis proses alam bawah sadar pada kajian drama. Hasil penelitian ini adalah menemukan wujud unsur-unsur inrinsik dalam naskah drama Musichall karya Jean-Luc Legarce .

Penelitian ini dilakukan guna memenuhi skripsi. Berbeda dengan 
Ika NurDayana1), Hidayah Budi Qur'ani' ${ }^{2)}$ : Refresentasi Gangguan Psikologis Tokoh

Orang Pertama dan Orang Kedua dalam Naskah Drama " Aljabar" Karya Zak Sorga:

Te;aah Psikologi Sastra.

Website : https://jurnal.umj.ac.id/index.php/penaliterasi Email : penaliterasi@umj.ac.id

penelitian terdahulu, penelitian ini khusus berfokus pada bentuk-bentuk gangguan psikologis yang terjadi pada

tokoh orang pertama dan orang kedua,dan faktor-faktor yang mempengaruhi gangguan psikologis tokoh orang kedua pertamadan orang kedua yang berdampak pada kepribadian, serta relevansi yang

terkadung pada naskah "ALJABAR" pada permasalahan gangguan psikologi yang sangat kurang diketahui oleh masyarakat saat ini. Pada penelitian ini memiliki tiga fokus penelitian yang pertama, mendeskripsikan bentuk-bentuk gangguan psikologis yang dialami oleh tokoh Orang Pertama dan tokoh Orang Kedua. Kedua, menganalisis faktor-fator yang mempengaruhi timbulnya gangguan psikologis yang diderita oleh, tokoh Orang Pertama da Orang Kedua. Ketiga, mnganalisis ketrkaitan naskah drama "ALJABAR" dengan adanya permasalahan gangguan psikologis yang terjadi pada kehidupan sehari-hari.

Ganguan psikologis yang terjadi pada tokoh orang kedua tersebut lebih dominan dari permasalahan yang terdapat didalam naskah. Permasalahan yang diambil dari dalam naskah "ALJABAR" dapat dirumuskan sebagai berikut: 1) Apa saja faktor faktor yang mempengaruhi gangguan psikologis tokoh orang pertama dalam naskah "ALJABAR". 2) Bagaimana bentuk gangguan psikologis yang terjadi pada tokoh orang pertama. 3) Bagaiamana relevansi gangguan psikologis yang terdapat pada naskah "ALJABAR" dengan permasalahan kehidupan sehari-hari.

Penelitian ini bertujuan untuk meberikan kontribusi pada teori psikologi sastra dalam mengungkap aspek-aspek gangguan psikologis serta dampaknya bagi kehidupan. Secara praktis penelitian ini diharapkan mampu memudahkan pembaca mencari referensi penelitian karya sastra terutama yang berhubungan dengan psikologi sastra. Untuk mengupas secara tuntas gangguan psikologis yang dialami tokoh orang kedua serta faktor-faktor yang mempengaruhi gangguan psikologis pada tokoh orang kedua tersebut,digunakana teori Psikoanalisis dan Dinamika Kepribadian Sigmund Freud.

\section{METODE PENELITIAN}

Jenis penelitian ini adalah penelitian kualitatif.Pendekatan yang digunakan pada penelitian iniadalah pendekatan psikologi sastra.Metode yang digunakan untuk mengkaji naskah drama "ALJABAR" adalah metode deskriptif analitik. Instrumen yang digunakan adalah human instrumen (penelitian sendiri). Adapun alat bantu yang digunakan untuk penelitian ini meliputi, buku teori yang berkaitan dengan fokus penelitian,media teknologi yang digunakan untuk mengakses jurnal penelitian yang berkaitan dengan masalah penelitian. Adapun alat bantu dalam penelitian ini adalah kartu data yang digunakan untuk mencatat dan mendiskripsikan seluruh data yang diperoleh.

Sumber data penelitian ini berupa naskah drama "ALJABAR" karya Zak Sorga dan terdiri dari 333 dialog. Naskah drama ini mengisahkan tentang kehidupan dua orang pelukis yang mengalami gangguan psikologis dan dilatarbelakngioleh faktor masalalunya yang kelam. Data yang dianalisis adalah dialog, kalimat-kalimat dalam paragraf, dan perilaku yang menggambarkan bentuk-bentuk gangguan psikologis dan fakto-faktor yang mempengaruhi gangguan psikologis tokoh orang kedua dalam naskah drama "ALJABAR".

eknik pengumpulan data yang digunakan dalam penelitian ini 
Ika NurDayana1), Hidayah Budi Qur'ani' ${ }^{2)}$ : Refresentasi Gangguan Psikologis Tokoh Orang Pertama dan Orang Kedua dalam Naskah Drama " Aljabar" Karya Zak Sorga: Te;aah Psikologi Sastra.

Website : https://jurnal.umj.ac.id/index.php/penaliterasi Email : penaliterasi@umj.ac.id

menggunakan teknik studi dokumen yang berupa pertma,membaca dengan cermat keseluruhan isi yang terdapat naskah drama yang dipilih sebagai fokus penelitian,dalam hal ini yaitu gangguan psikologis dan faktor gangguan psikologis tokoh orang kedua. Kedua meencari bagian-bagian tertentu yang berkaitan dengan gangguan psikologis dan faktor gangguan psikologis tokoh orang pertama dan orang kedua, dan yang ketiga menandai bagian-bagian tertentu yang diasumsikan mengandung unsur psikologi id, ego, superego dan dinamika kperibadian tokoh orang pertama, 4) Mencatat hasil deskripsi tentang psikologi id,ego dan superego tokoh orang pertama.

Teknik analisis data yang digunakan pada naskah drama "ALJABAR" adalah teknik analisis isi, yaitu mengkaji keseluruhan isi teks pada naskah drama "ALJABAR". Hal ini dimulai dari struktur internal pada teks darma, kemudian menemukan hal yang berkaitan dengan tokoh orang kedua dan menghubungkan dengan isi psikologis tokoh pada naskah drama tersebut. Pengolahan data yang telah terkumpul kemudian dianaisis dengan cara mengklasifikasi data yang terkumpul berdasarkan kategori yang dapat menjawab rumusan masalah.

Pengecekan keabsahan data yang dilakukan dalam penelitian ini yaitu, dengan cara ketekunanan pengamatan membaca dan diskusi dengan teman sejawat. Ketekunan pengamatan dilakukan dengan cara membaca dan memahami secara teliti terhadap berbagai hal yang berkaitan dengan permasalah penelitian. Permasalahan penelitian yang dimaksud adalah gangguan psikologis dan faktor yang mempengaruhi gangguan psikologis yan terjadi dalam naskah drama "ALJABAR". Peneliti melakukan diskusi dengan teman sejawat merupakan salah satu cara yang digunakan untuk memeriksa kevalidan data, adanya cara tersebut dapat mempermudah peneliti dalam proses pengecekan keabsahan data.

\section{HASIL DAN PEMBAHASAN}

Psikologi merupakan sebuah ilmu yang mempelajari serta memehami perilku manusia yang dialami dalam kehidupannya (Walgito, 2010, hal. 240). Dalam naskah drama "ALJABAR" terdapat cerita fiksi yang berisikan cerita tentang seorang tokoh dan kepribadian yang berbeda pada umunya. Tokoh orang pertama dan orang kedua yang mengalami ganggauan psikologis yang dipengaruhi oleh masalalunya. Gangguan psikologis yangg terjadi mengakibatkan kepribadiannya dan kejiwaan tokoh orang pertama menjadi tidak stabil. Sesuai dengan judul pada objek material penelitian, naskah drama " $A L J A B A R$ " menyajikan kisah kehidupan sosial tokoh orang pertama dan orangkedua yang penuh tekanan dari masalalunya sehingga mengakibatkan gangguan psikologis yang terjadi pada dirinya.

\section{Representasi Gangguan Psikologis Tokoh Orang Pertama dan Kedua}

Berdasarkan hasil analisis

ditemukan bahwa bentuk gangguan psikologis tokoh orang pertama meliputi: (1) Emosi, yaitu pengalaman yang ada pada diri individu disadari dan diaktifkan baik oleh perangsang eksternal maupun oleh bermacam-macam dalam jasamni yang mengakibatkan suatu ketegangan anatara id , ego, dan superego. (2) Seks, yaitu dorongan sekssual yang ada pada individu 
Ika NurDayana1), Hidayah Budi Qur'ani' ${ }^{2)}$ : Refresentasi Gangguan Psikologis Tokoh Orang Pertama dan Orang Kedua dalam Naskah Drama " Aljabar" Karya Zak Sorga: Te;aah Psikologi Sastra.

Website : https://jurnal.umj.ac.id/index.php/penaliterasi Email : penaliterasi@umj.ac.id

yang merujuk pada kesenangan yang tidak terbatas pada pemuasan gentikal. (3) Agresi, yaitu dorongan yang dilakuan secara sengaja baik secara fsisk maupun verbal dengan tujuan merusak dan dengan adanya tujuan terakhir adalah penghancuran diri sendiri yang berujung pada kemtian. (4) Kecemasan, yaitu perasaan yang tidak menyenangkan dan sulit dipastikan namun selalu terasa yang dialami oleh individu dengan taraf dan kadar yang berbeda-beda.

\section{Emosi}

Emosi yang ada pada diri suatu individu merupakan,situasi pada diri individu yang menunujukan perasaan intens akan sesuatu yang ada sekitarnya maupun pengalaman dialami semasa hidupnya dan tindakan yang ditimbulkannya mengakibatkan meningkatnya ketegangan. Kutipan dibawah ini yang menunjukkkan tokoh orang kedua yang mengalami emosional. Kutipan dibawah ini mengambarkan bentuk nyatagangguan psikologis yang dialami tokoh orang pertama yang berperilaku emosi.

D1.

ORANG I : Bangsat! Anjing!

(merobek-robek lukisan)

ORANG II : Setan alas! (merobekrobek lukisan) (mereka melukis

lagi dengan keringat yang

bercucuran)

( Zak Sorga,2010:287-288).

Kutipan dialog diatas menggambarkan tokoh orang pertama yang mudah marah. Sifat yang ada pada tokoh orang kedua tersebut ia tunjukan pada tokoh orang ke satu dengan sering

bernada tinggi. Tokoh orang kedua memilki emosi karena adanya dorongan id yang membuat tokoh orang pertam emosi dengan nasihat yang diberikan orang kedua yang membritahukan akan apa yang harus ia lakukan dalam pekerjaanya. Dorongan ego yang ada diri tokoh orang pertama ditujukan untuk meluapkan rasa marahnya kepada otokoh orang kedua,

tetapi, superego yang ada didalam diri tokoh orang pertama untuk tetap bersabar dantidak terlalu berapi-api dalam menhadapi perselisisihanya dengan tokoh orang kedua.

Hasil analisis kutipan diatas menunujukan adanya sifat yang terjadi pada tokoh orang kedua pada naskah drama "ALJABAR" tersebut sejalan dengan teori Krech (dalam Andalas, Qur'ani,2017:263) bahwa emosi yang ada pada tokoh orang pertama didadasri dengan adanya suatu kebencian kepada orang lain yang menjadikan tokoh orang pertama tidak akan pernah merasakan kepuasan dan selalu berusaha untuk menjatuhkan orang ada didektanya termasuk tokoh orang kedua. Emosi yang ada pada diri manusia memiliki perkembangan dimana suatu individu memiliki kemampuan untuk mengendalikan maupun meninjau secara langsung jalan emosi yang ada pada dirinya maupun orang lain (Grosh \& Jhon, 2011:66). Emosi yang terjadi pada tokoh orang pertama merupakan salah satu bentuk perubahan sosial dimana pada perbahan tersebut terjadi karena, adanya faktor jenis gender laki-laki, yang lebih dominan jika dibandingkan oleh kaum wanita (Santrock, 2013:6)

D2.

ORANG I : Bohong. Kemana larinya coretan -coretan yang dulu, keman larinya tokoh-tokohku. Kita bukan pelukis, mari kita robek lukisan-lukisa kita. (mengambil lukisan dan merobekrobek) (Zak Sorga,2010:105). 
Ika NurDayana1), Hidayah Budi Qur'ani' ${ }^{2)}$ : Refresentasi Gangguan Psikologis Tokoh

Orang Pertama dan Orang Kedua dalam Naskah Drama " Aljabar" Karya Zak Sorga:

Te;aah Psikologi Sastra.

Website : https://jurnal.umj.ac.id/index.php/penaliterasi Email : penaliterasi@umj.ac.id

\begin{abstract}
Kutipan dialog diatas dapat memperkuat adanya gangguan psikologis pada emosi tokoh orang pertama yang sangat menggebu-gebu. Dimana id yang pada diri tokoh orang pertama bersebrangan dengan id yang ada pada diri tokoh orang kedua, ada perbedaan keinginan tersebut membuat tokoh orang pertama yang tidak menahan emosinya, karena tidak bisa
\end{abstract}

menerima pernyataan yang dilontarkan oleh tokoh orang kedua.

Hasil analisis kutipan diatas dapat meperkuat gangguan psikologis yang dierita tokoh orang pertama bahwasanya ia mudah sekali untuk marah dan tidak bisamengendalikan emosi yang ada dalamdirinya dengan bijaksana. Keadaan psikologis tokoh orang pertama yang mendapat dorongan kuat dari id dan tidak bisa terkendalikan oleh ego yang ada pada dirinya sementara, ego yang ada pada diri tokoh orang kedua tidak sejalan dengan apa yang ada pada tokoh orang pertama dengan adanya perbedaan tersebut tidak jarang terlihat percikan konflik yang terlihat pada setiap percakapan mereka, yang tidak sejalan (Freud,2017:33). Pada diri manusia emosi terbentuk dari pengalaman yang dilalui oleh suatu individu maupun secara biologis maupun secara psikologis. Emosi yang terjadi pada tokoh orang pertama memberikan adanya pengamlaman yang bersifat subjektif serta mengakibatkan adanya amarah dalam dirinya yang diluapkan langsung kepada lawan biacaranya .

\section{Seks}

Seks merupakan sebuah dorongan yang memiliki tujuan kesenangan, dorongan seksual yang terdapat pada diri suatu individu tidak bisa diubah, akan tetapi jalur yang menjadi dorongan seks tersebut untuk mencapai tujuannya dapat bervariasi, karena jalur dorongan tersebut bersifat fleksibel. Seks memiliki berbagai bentuk,termasuk dalam naskah drama "ALJABAR" ini terdapat salah satunya adalah sadisme (sadism), jenis seks ini kebutuhan yang umum dan muncul dalam suatu hubungan seksual.Berikut merupakan kutipan yang menggam barkan gangguan psikologis orang pertama.

D1.

ORANG II: Lantas apa mamumu?

ORANG I :Ngeseks. Berilah aku seks

ORANG II : Aku tidak mau.

ORANG I : Lakukan kalau kau mau berlanjut .

ORANG II : Aku tidak bisa. (Zak Sorga,2010:136-140)

Kutipan dialog diatas menggambarkan keadan gangguan yang dialami tokoh orang pertama yang ingin dipuaskan hasratnya dan dipenuhi oleh tokoh orang kedua. Permintaan seks yang diajukan oleh tokoh orang pertama tersebut semata-mata terjadi karena adanya dorongan kesenangan pemuasan genital yang ada pada dirinya. Dorongan sesksual ini semakin terpangaruh oleh keadaan id yang ada pada diri tokoh yang penuh akan kesenangan ,dan selalu ingin dipuaskan oleh ego.

Hasil analisis kutipan diatas dapat memperkuat adanya ganguan psikologis seks dari tokoh orang pertama yang meminta dilayani hasratnya oleh tokoh orang kedua. Seluruh tubuh manusia dialiri oleh libido, tujuan utama dari doronga seksual tokoh orang pertama tidak bisa diubah, akan tetapi jalur yang ditempuh dorongan-dorongan seksual tokoh orang pertama tersebut bervariasi (Freud, 2017:35). Dorongan seks yang ada tokoh orang pertama tersebut bersumber dari adanya id yang tidak dipenuhi oleh ego. 
Ika NurDayana1), Hidayah Budi Qur'ani' ${ }^{2)}$ : Refresentasi Gangguan Psikologis Tokoh Orang Pertama dan Orang Kedua dalam Naskah Drama " Aljabar" Karya Zak Sorga: Te;aah Psikologi Sastra.

Website : https://jurnal.umj.ac.id/index.php/penaliterasi Email : penaliterasi@umj.ac.id

Dorongan seks yang terjadi tersebut mengakibatkan adanya suatu pemaksaan yang dilakukan oleh, tokoh orang pertama yang mengarah pada adanya pemaksaan yang berujung pada kekerasan sesksual (Poerwandari, 2011:192).

D2.

ORANG II : Enam tahun kemudian, setelah aku lupa, pelacur itu kembali dengan bayi di pangkuannya, dia bilang bayi itu adalah anakku, aku marah, tapi kemarahan itu tiba-tiba, hilang karena gairah seksku naik dan pelacur itu kuperkosa sampai mati.

\section{(Zak Sorga,2010:164).}

Pada kutipan diatas menggambarkan adanya dorongan seks yang ada diri tokoh kedua dorongan yang datang dari id yang ingin dipuaskan segala keinginananya oleh ego. Adanya dorongan seks maupun dorongan id yang sangat kuat mengakibatkan timbulnya seks jenis sadisme (sadism). Dorongan seks yanga pada tokoh orang kedua mengakibatkan adanya kematian dari pelcur yang diperkosanya tersebut.

Hasil analisis pada kutipan diatas dismpulkan adanya dorongan seks yang bersumber dari id yang sangat berapi-api mengkibatkan ego dan superego kuwalahan dalam menyikapi dorongan sesksual tersebut. Pada hakikatnya dorongan sesksual yang ada pada diri suatu invidu memiliki tujuan untuk kesenengan (Freud ,2017:40). Jenis dorongan sesks yang yang ada pada diri tokoh orang kedua tersbut merupak seks jenis sadisme (sadism)adalah kebutuhan terpenuhinya akan

kesenangan seksual yang bersifat menyakiti atau menimbulakan kecelakaan atau kematian. Dorongan seks sadisme (sadism), yang dituangkan tersebut berupa danya suatu pemaksaa yang dilakuakan oleh tokoh Orang Kedua dan berujung pada terjadinya kekersan seksual yang dialami oleh pelacur dan dilakukan oleh tokoh Orang Kedua. Kekerasan sesksual tersebut meberikan dampak kerugian yang harus dialami oleh tokoh orang kedua, baik secara fisik maupu psikis ( Sisca \& Moningka, 2011: 193)

\section{Agresi}

Dorongan agresi yang ada pada suatu individu merupakan bentuk dari isyarat yang menunjukan adanya kebutuhan pada suatu individu untuk mengendalikan dorongan agresi yang ada pada dirinya. Dorongan agresi yang ada pada individu memiliki tujuan untuk merusak yang berujung pada pengahncuran diri. Dalam naskah aljabar tokoh orang pertama yang mengalami adanya dorongan agresi pada dirinya berubah dalam bentuk menikmati penderitaan tokoh orang kedua. Seperti yang digambarkan pada kutipan dibawah ini.

D1. ORANG I :Kita ini pasienpasien dokter. Ajarilah aku bagaimana caranya untuk bunuh diri ,itu akan lebih baik.

ORANG II : Kau harus membunuhku (Zak Sorga,2010:171-172).

Kutipan pada dialog diatas menggambarkan adanya agresi yang terjadi pada tokoh orang kedua yang ingin mengakhiri hidupnya. Dalam kondisi ini keinginan tokoh orang pertama yang sangat kuat ingin menghancurkan dirinya sangat terlihat dimana ia meminta tokoh orang kedua untuk mengakhiri hidupnya. Dengan adanya pernyataan ini sejalan denga teori psikoanalisis Freud yang menjelaskan bahwasanya dorongan agresi 
Ika NurDayana1), Hidayah Budi Qur'ani' ${ }^{2)}$ : Refresentasi Gangguan Psikologis Tokoh

Orang Pertama dan Orang Kedua dalam Naskah Drama " Aljabar" Karya Zak Sorga:

Te;aah Psikologi Sastra.

Website : https://jurnal.umj.ac.id/index.php/penaliterasi Email : penaliterasi@umj.ac.id

yang ada pada tokoh orang pertama mengakibatkan adanya dorongan untuk mengakhiri hidupnya (Freud,2017:34-35).

Hasil analis dari kutipan dialog diatas memperkuat adanya dorongan agresi yang ada pada tokoh orang kedua dimana dalam keadaantokoh orang kedua psikologis ego yang ada pada dirinya sangat terancam oleh id yang memaksa persaan-perasaan yanga ada pada diri tokoh orang pertama ranah alam tak sadar. Jadi, dorongan agresi yang sangat kuat pada diri tokoh orang kedua mengakibatkan dorongan untuk samasama mengakhiri hidupnya serta saling bergulat untuk saling menaklukkan sehingga, kedua prisnsip tersebut harus tunduk pada salah satu pada prinsip realitas yang mewakili adanya tuntutan dari dunia luar (Freud,2017:36-38). Agresi yang pada diri suatu idnividu dapat muncul dari adanya kejadian maupun situasi yang kurang menyenangkan pada lingungan sekitarnya (dalam Guswani, 2011:87). Agresi yanga terjadi pada tokoh Orang Kedua tersebut karena, adanya tekanan yang diberikan oleh lingkungan sekitar yang memungkinkan munculnyasituasisituasi yang tidak menyenangkan sehinggga mengakibatkan adanya agresi pada tokoh Orang Kedua.

$$
\begin{aligned}
& \text { D2. ORANG I : Kaulah } \\
& \text { yang wajib membunuhku } \\
& \text { ORANG II: Tolong } \\
& \text { bunuhlah aku (Zak } \\
& \text { Sorga,2010:173-174). }
\end{aligned}
$$

Kutipan pada dialog diatas menggambarkan adanya dorongan untuk mengakhiri hidupnya yang dialami oleh tokoh orang pertama. Dorongan yang dialami oleh kedua ini sangat dominan pada dirinya. Adanya dorongan ini disebabkan adanya faktor masalalu yang dialami oleh tokoh orang kedua yang mengakibatkan adanya dorongan-dorongan untuk mengakhiri hidupnya (Freud,2017:36-37).
Hasil analisis pada kutipan dialog diatas memeperkuat adanya dorongan agresi yang tidak hanya dialami oleh orang tokoh kedua, tokok orang pertama yang juga mengalami dorongan ini. Dorongan agresi yang dialami oleh tokoh orang pertama ini berawal dari kondisi psikisnya yang kecemasan dimasalalu yang pernah ia lakukan sehingga mengakibatkan hiangya nyawa pelacur yang bersamanya,dengan adanya bayangan masalalu tersebut mengakibatkan dorongan untuk mengakhiri hidupnya (Fiest,2017:55-56). Masalalu yang dialami oleh kedua tokoh pada naskah drama "ALJABAR" merupakan salah satu faktor munculnya agresi yang dialami keduatokoh tersebut memberikan dorongan yang selalu ingin megakhiri hidupnya.

\section{Kecemasan}

Kecemasana adalah situasi yang ada pada diri suatu individu merupakan salah satu dampak dari gangguan psikologis yang sudah menjadi bagian dalam kehidupan sehari-hari yang tak terhindarkan. Kecemasan memiliki fungsi dimana ego yang ada pada suatu individu yang merasakan akan tentang adanya kemungkinan datangnya suatu bahaya, sehingga pada situasi individiu dapat mempersipakan reaksi adiftif yang sesuai. Adapun kecemasan yang terjadi pada tokoh orang pertama dalam kutipan dibawah ini.

D1.

ORANG II : Kita belum lagi mulai.

ORANG II: Sekarang semuanya sudah malam.

ORANG II : Kita belum lagi menemukan pagi .

ORANG I : Pagi tak akan pernah datang .

ORANG II : Matahari harus terbit.

ORANG I : Oh... aku hanya ingin tahu apa kegelisahan hanya milik kita berdua. 
Ika NurDayana1), Hidayah Budi Qur'ani' ${ }^{2)}$ : Refresentasi Gangguan Psikologis Tokoh

Orang Pertama dan Orang Kedua dalam Naskah Drama " Aljabar" Karya Zak Sorga:

Te;aah Psikologi Sastra.

Website : https://jurnal.umj.ac.id/index.php/penaliterasi Email : penaliterasi@umj.ac.id

ORANG II : Sudah pasti tidak ada dunia lain kecuali dalam batin kita (Zak Sorga,2010:4-10)

Kutipan pada dialog diatas melukiskan bagaimana kecemassan yang dialami oleh tokoh orang pertama dan orang kedua. Kecemasan yang dialami tersebut menjadikan adanya gangguan psikologispada tersebut. Adanya kecemasan tersebut didasari akan keputusasaan menjalani kehidupan yang dialami tokoh orang pertama dan orang kedua. Dari keptusasaan tersebut semakin memicu kecemasan yang menghantui tokoh orang pertama dalam menjalani hidupnya.

Hasil analisis dari kutipan data diatas sangat menggambarkan adanya kecemasan yang ditimbulkan dari keputuasaan dari kedua tokoh tersebut. Dimana dalam diri jiwa tokoh pertama maupun dua memiliki persmaan akan ego yang tidak mampu mengontrol tekanan atau dorongan dari id. Adanya keputusasaan dan ketakutan yang dirsakan oleh kedua tokoh tersebut sangat mempengaruhi jalan kondisi dari psikologis bagi kelangsungan hidup dari tokoh orang pertama maupun tokoh orang kedua. Kecemasan yang dialami oleh tokoh orang kedua ini adalah kecemasan realisti (realistic anxiety) dimana adanya perasaan yang tidak menyenangkan dan tidak spesifik yang mencakup kemungkinan bahaya yang akan dialaminya. (Freud,2015:23-24).

D2.

ORANG I : (ketakutan) Diamlah!

Kau lihat kanvas-kanvas itu bergerak mereka meminta nyawa, mereka minta hidup, mereka minta nafas, kita dikukurng oleh kanvas -kanvas. Tolonglah aku, aku lapar, aku haus, aku muak (tak ada jawaban) kenapa kau biarkan aku tenggelam dalam diamku yang, gaduh ini.

(Zak Sorga,2010:204)
Kutipan diatas melukiskan akan adanya kecemasan yang dialami oleh tokoh orang pertama saat mendapati akan adanya kegelisahan dalam hatinya. Kecamasan yang timbul dari adanyatekanan dari id dan tidak bisa diimbangi oleh ego yang tidak siap menghadap kenyataan, bahwasanya tokoh orang pertama dalam naskah tersebut, sudah terlalu tertinggal jauh dari semua orang yang sudah banyak mengalami kemjuan dibandingkan dengan mereka yang meraa tidak mengalami kemajuan daam kehidupan.

Hasil analisis dari data diatas sangat meyakinkan akan adanya kecemasan yang timbul dari dalam diri tokoh orang pertama. Kecamasan yang disebabkan dari ketakutan akan ketertinggalan mereka yang jauh dari pesatnya perkembangan pada era itu. Hal yang terjadi pada tokoh orang utama yang disebabkan id yang yang sangat memegang penuh kendali akan jiwa orang pertama, sehingga tokoh orang pertama menjadi ketakutan atau kecemasan. Jenis kecemasan yang dialami oleh tokoh orang pertama ini adalah jenis kecemasan realistis. Kecemasan reaistis ini merupakan adanya situasi yang tidak menyenangkan dan tidak spesifik mencakup kemungkinan adanya bahaya yang dirsakan oleh tokoh orang kedua (Freud,2017:37).

\section{Faktor yang Mempengaruhi Gangguan Psikologis}

Berdasarkan hasil analisis,ditemukan adanya faktor yang mempengaruhi ganggguan psikologis dari tokoh orang kedua diantaranya adalah faktor masalalu. Ketidaksadaran personal yang ada pada suatu individu dibentuk oleh adanya pengalaman-pengalaman individu semasa hidupnya. Pengalaman masalalu yang ada pada ingatan tokoh orang pertama dalam naskah 
Ika NurDayana1), Hidayah Budi Qur'ani' ${ }^{2)}$ : Refresentasi Gangguan Psikologis Tokoh

Orang Pertama dan Orang Kedua dalam Naskah Drama " Aljabar" Karya Zak Sorga:

Te;aah Psikologi Sastra.

Website : https://jurnal.umj.ac.id/index.php/penaliterasi Email : penaliterasi@umj.ac.id

"ALJABAR" membuat ia selalu tergiang-ngiang akan tindakan permerkosaan yang dilakuknanya hingga merenggut nyawa pelacur tersebut.

\section{Faktor Masalalu}

Kehidupan manusia tidak pernah terlepas kegiatan sosial dan bersolisasi dengan mnusia lain, sehingga menimbulkan adanya ingatan pengalaman masalalu dalam hidupnya. Banyak yang tidak menyadari akan gangguan psikologis yang dipengaruhi oleh pengalaman masalalu yang dialami oleh suatu individu. Seperti tokoh orang kedua pada naskah "ALJABAR" yang memiliki ingatan masalalu yang selalu menghantuinya dan mengakibatkan emosional yang sangat tinggi pada kepribadian tokoh . Dibuktikan pada kutipan dialog berikut.

D1.

ORANG II:Kau keterlaluan, kau telah mengungkit masa laluku. Ayo berdirilah disitu (Zak Sorga.2010:146).

Kutipan dialog diatas menggambarkan dengan jelas adanya ingatan yang masalalu yang melintas pada ingatan tokoh orang kedua yang teringat akan masalalu yang ia pernah lakukan. Adanya tekanan pada ingatan masalalu tokoh oranng keduan mngakibatkan adanya tekanana pada ego yang mengakibatkan timbulnya emosi dalam dirinya.

Hasil analisis dari data diatas memeperkuat adanya faktor masalalu yang berpengaruh pada gangguan psikologis yang diderita oleh tokoh orang kedua. Adanya tekanan dari ingatan masalalu tokoh orang kedua dalam nasakah drama "ALJABAR" mengakibatkan adanya

dorongan pada ego yang ada pada diri tokoh orang kedua yang bersumber dari area pikiran alam sadarnya yang berinteraksi dengan dunia luar (Freud,2015:31). Adanya dorongan tersebut dengan secara langsung

mempengaruhi kepribadian tokoh orang kedua yang mudah marah dan berpengaruh pada kehidupan yang saat ini dijalani.

D2.

ORANG II : Kau adalah rentetan dari kejadian itu.

ORANG I: Maksudmu?

ORANG II : Enam tahun kemudian, setelah aku lupa, pelacur itu kembali dengan bayi di pangkuannya, dia bilang bayi itu adalah anakku, aku marah, tapi kemarahan itu tiba-tiba, hilang karena gairah seksku naik dan pelacur itu kuperkosa sampai mati. (Zak Sorga.2010: 162165).

Kutipan dialog diatas menggambarkan bahwasanya faktor masalalu yang ada pada tokoh orang kedua bersumber pada orang pertama yang tidak lain adalaha anaknya.Adanya ingatan masalalu yang terngiang-tengiang dikepala tokoh orang kedua mengakibatkan ketidak stabilan pada emosi dan kecemasana yang ada pada jiwanya. Ingatan masalalu pembunuhan dan pemerkosaan keji yang dilakukan oleh tokoh orang kedua sehingga mengakibatkan pelacur yang menjadi ibu dari anaknya tersebut tewas. Kematian dari pelacur tersebut disebabkan dengan adanya dorongan sesksual yang berlebihan dari tokoh orang kedua.

Hasil analisis pada kutipan diatas dismpulkan adanya faktor masalalu yang ada pada tokoh orang kedua bersumber dari tokoh orang pertama yang tidak lain adalah anaknya. Perasaan menyesal dari tokoh orang 
Ika NurDayana1), Hidayah Budi Qur'ani' ${ }^{2)}$ : Refresentasi Gangguan Psikologis Tokoh Orang Pertama dan Orang Kedua dalam Naskah Drama " Aljabar" Karya Zak Sorga: Te;aah Psikologi Sastra.

Website : https://jurnal.umj.ac.id/index.php/penaliterasi Email : penaliterasi@umj.ac.id

kedua yang bergejolak dihatinya menyebabkan kecemasan yang bersumber dari konflik ego dan superego. Kecemasan yang muncul dari tokoh Orang Kedua ini bersumber dari dorongan seks yang akan dilampiaskan pada pelacur tersebut karena adanya gejolak antara ego dan id yang ada pada diri tokoh Orang Kedua. Dorongan seks yang terjadi tersebut mengakibatkan terjadinya kekerasan seksual yang harus dialami oleh pelacur sehingga mengakibatkan kematian pelacur tersebut (Poerwandari, 2011:192).

\section{KESIMPULAN}

Berdasarkan hasil identikasi , pengamatan dan pembahasan terhadap hasil peneliti dari naskah drama "ALJABAR" karya Zak Sorga. Diproleh adanya empat jenis bentuk gangguan psikologis yang diderita oleh tokoh orang kedua berupa emosi, sesks, dan kecemasan dari kempat gangguan psikologis yang terjadi pada tokoh orang pertama dan orang kedua sangat mempengaruhi keberlangsungan hidup dari tokoh kedua tersebut.

Gagngguan psikologis yang dialami oleh tokoh orang kedua yanga ada pada naskah "ALJABAR" karya Zak Sorga bersumber dari tokoh utama yang tidak lain adalah saksi bisu kelamnya masalalu tokoh orang kedua yang menghabisi nyawa pelacur yang ia bunuh dan perkosa didepan mata tokoh orang kedua, sehingga dengan adanya kejadian tersebut mengakibatkan adanya ingatan akan kecemasan terhadap apa yang ia lakukan dimasalalunya, sehingga dari faktor masalalu yang ada pada diri tokoh orang kedua mengakibatkan adanya gangguan psikologis yang mempengaruhi kehidupannya. Relevansi naskah drama "ALJABAR" ini dengan kehidupan nyata saat ini sangat

\section{REFERENSI}

Alwisol.2016.Psikologi

Kepribadin.Malang:UMM Press.

Andalas,Eggy Fajar dan H. B. 2017. Narasi Katulistiwa .Malang:Kota Tua.

Anwar,Fuadi.M. (2011). Dinamika Psikologis Kekerasan Seksual: Sebuah Studi Fenomenologi . Jurnal Psikologi Islam .Vol.8 No.2 Hal.192-208.

Buana Putra.2015. Skripsi.Kajian Psikoanalisis Tokoh-Tokoh Dalam Naskah Drama Music-Hall Karya Jean-Luc Lagarce.Universitas Negri Yogyakarta.

Bonar, H. (2011). Emotional Intelegence dan Psychological Well-being pada Manusia Lanjut UsiaAnggota Organisasi berbasis. INSAN.Vol. 13 No.02 Hal 64-72.

Desmita. 2014. Psikologi Perkembangan Peserta Didik.Bandung. Remaja Rosdakarya.

Guswani, A. M. (2011 ). Perilaku Agresi Pada Mahasiswa Ditinjau Pada Dari Kematangan Emosi . JurnalPsikologi Pitutur, Volume I, No 2,Hal.686-92.

Fiest, G. F.A. 2017. Teori Kepribadian.Jakarta Selatan: Salemba Humanika.

Nofitra, M. H. (2017). Kajian Psikoanalisis Dalam Novel Pria Terakhir Karya gusnaldi. Jurnal Pendidikan Rokania, 70-89. 
Ika NurDayana ${ }^{1)}$, Hidayah Budi Qur'ani ${ }^{2)}$ : Refresentasi Gangguan Psikologis Tokoh Orang Pertama dan Orang Kedua dalam Naskah Drama " Aljabar" Karya Zak Sorga: Te;aah Psikologi Sastra.

Website : https://jurnal.umj.ac.id/index.php/penaliterasi Email : penaliterasi@umj.ac.id

Ratna, Nyoman Kutha.2007.Teori Metode, dan Teknik Penelitian

Sastra.Yogyakarta: Pusataka Pelajar.

Walgito,B.2010.Pengantar Psikologi Umum.Yogyakarta:Penerbit Andi.

Saraswati,E.R.2011. Pribadi Dalam Novel Ayat-Ayat Cinta Dan Laskar Pelangi:Telaah Psikoanalisis Sigmund Freud. Jurnal Artikulasi, Vol.2 No.12 Hal 883-900.

Zaenuri,A.2008. Esestika Kesadaran :Konsep Seni Menurut Sigmund Freud.Academia.edu.Hal.1-14. 